\title{
Effect of Metal Ions on ALP Activities in Raw and Pasteurized Milk
}

\author{
Hetvi Patel ${ }^{[1]}$, Abhay Koladiya ${ }^{[2]}$, Divyesh Chauhan ${ }^{[3]}$ \\ ${ }^{[1,2]}$ Final Year Student, Department of Food Processing Technology, \\ A.D. Patel Institute of Technology, New Vallabh Vidyanagar, Gujarat, India. \\ ${ }^{[3]}$ Consultant, Vidya Dairy, Anand Agriculture University campus, Anand, Gujarat, India.
}

\begin{abstract}
This study was aimed to examine the activity of alkaline phosphatase enzyme in pasteurized milk upon addition of different metal ions. Here we have taken 5 sets of 5 metal ions with different concentration to check out the effect of metal ions on the reactivation of alkaline phosphatase enzyme into the pasteurized milk. It was observed that certain metal ions are exhibiting the reactivation of alkaline phosphatase enzyme into the pasteurized milk and shows AP test positive while certain metal ion is highly inhibiting the reactivation of alkaline phosphatase enzyme and shows the AP test negative in the pasteurized milk.
\end{abstract}

Keywords: Alkaline phosphatase enzyme, Pasteurized milk, Metal ions, Alkaline phosphatase enzyme reactivation.

\section{INTRODUCTION}

As a leading producer of the milk, Indian dairy sectors are growing widely. Now they focus mainly on the quality of the milk and milk products. In any dairy industry the basic test for identifying the quality of the raw milk are the organoleptic, \%Fat, \%SNF, $\%$ acidity, COB and MBRT while for the pasteurized milk the basic tests are ALP activity test, MBRT, \%Fat, \%SNF are there. These tests are popular all around the globe to perform. AP test helps in knowing the activity of alkaline phosphatase enzyme in the milk. Now as farming system of India and its different region the quality of milk will differ from each other like there may be presence of heavy metals in the raw milk which can affect the health of the humans. It comes to the milk via fodder. In many region of the India the presence of heavy metal ions are there. It does not only affect the health of the humans but also it affects the state of the soil and environment. The metals ions come from the fodder. Animals consume this fodder and when we secret the milk metals comes into the milk. The presence of metal ions causes damage to the human body like it directly effects on the liver and kidney and causes other diseases also.

\section{REAGENTS AND EQUIPMENT'S REQUIRED}

Water bath (D.K scientific technologies), Sodium carbonate (Merck specialities private limited, 1.93611.0521), Sodium bicarbonate (RFCL limited, 50680), PNPP (SISCO research laboratories private limited, 88485), Zinc (S D fine chem. Limited, 20297 k05), Silver (Merck specialities private limited, 61755900251730), Copper (Samir tech chem. Industry, 30310), Cobalt (Glaxo smithkline pharmaceuticals, 59876209), Calcium (Samir tech chem. Private limited, 910443), Manganese.

\section{PROCEDURE}

The study was aimed to metal ions influence on the quality of milk as ALP activity. Total 7 metal ions were tested for the activity of ALP on the raw and pasteurized milk. They were kept in the standard calibrated water bath. The 5 metals are Zinc (S D fine chem. Limited, 20297 k05), Copper (Samir tech chem. Industry, 30310), Cobalt (Glaxo smith Kline pharmaceuticals, 59876209), Calcium (Samir tech chem. Private limited, 910443) and Manganese. The samples were analysed at the interval of 30 minutes with standard methodology. The ALP activity was checked by $1 \mathrm{ml}$ raw and pasteurized milk sample in presterilized test tube (Borosil, 9830) followed by addition of different strengths of solutions like $0 . \%, 0.2 \%, 0.4 \%, 0.6 \%, 0.8 \%, 1.0 \%$ of each one of the five metals. After mixing it thoroughly with the raw and pasteurized milk $5 \mathrm{ml}$ of AP buffer PNPP (SISCO research laboratories private limited, 88485) which was earlier prepared in the buffer containing 1.5g of Sodium bicarbonate (RFCL limited, 50680) and $3.5 \mathrm{~g}$ of Sodium carbonate (Merck specialities private limited, 1.93611.0521) and adjusted its pH value 10.2 . The ALP activities were checked at the $37^{\circ} \mathrm{c}$ temperature by incubating test samples in standard water bath (D.K scientific technologies) which was previously calibrated before study. The yellow colour appearance indicated the presence of alkaline phosphatase enzyme which means the test is positive. All results as per the action plan were documented properly.

\section{RESULTS}

Here we have done the Alkaline phosphatase activity test on 5 different metals so for that to know the metal activity we have to know the at what time the alkaline phosphatase enzyme gets activate at what time. Here we have checked the time required in the pasteurized milk to reactivate the alkaline phosphatase enzyme which is 6 hours. So from this we can tell that at 6 hours the alkaline phosphatase enzyme gets activated in the milk. 
Table 1.Control sample readings

\begin{tabular}{|c|c|}
\hline \multicolumn{2}{|c|}{ PCM Control } \\
\hline Time (hrs.) & ALP activity +ve/-ve \\
\hline 0 & Negative \\
\hline 1 & Negative \\
\hline 2 & Negative \\
\hline 3 & Negative \\
\hline 4 & Negative \\
\hline 5 & Negative \\
\hline 6 & Positive \\
\hline 7 & Positive \\
\hline 8 & Positive \\
\hline 9 & Positive \\
\hline 10 & Positive \\
\hline 11 & Positive \\
\hline 12 & Positive \\
\hline 13 & Positive \\
\hline 14 & Positive \\
\hline 15 & Positive \\
\hline 16 & Positive \\
\hline 17 & Positive \\
\hline 18 & Positive \\
\hline 19 & Positive \\
\hline 20 & Positive \\
\hline 21 & Positive \\
\hline 22 & Positive \\
\hline 23 & Positive \\
\hline 24 & Positive \\
\hline
\end{tabular}

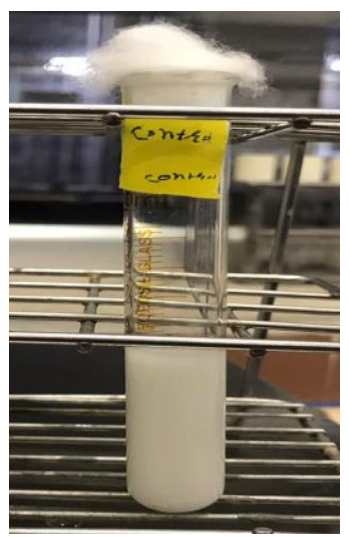

Figure 1.Reading of control samples at 0 hour

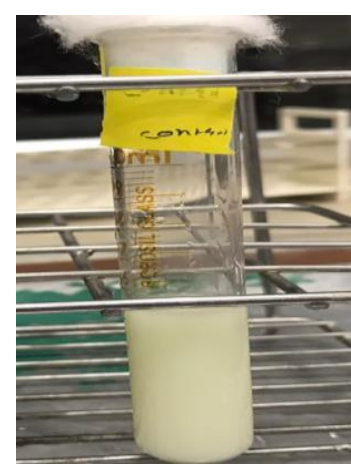

Figure 2. Reading of control samples at 6 hour 


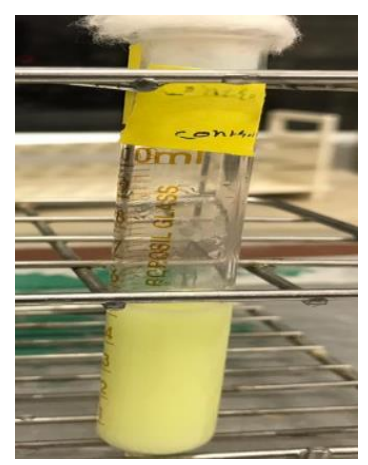

Figure 3. Reading of control samples at 12 hour

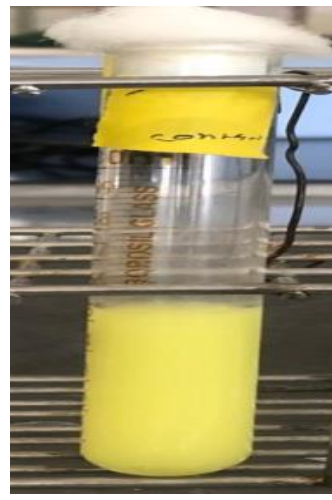

Figure 4. Reading of control samples at 24 hour

Copper (Samir tech chem. Industry, 30310)

We have checked the activity of metals on alkaline phosphatase enzyme reactivation. In this we have made different concentration of metal solution of $0.1 \%, 0.2 \%, 0.4 \%, 0.6 \%, 0.8 \%$ and $1.0 \%$ by this different concentration we can check the time required for the reactivation of the alkaline phosphatase enzyme in the pasteurized, milk. We have checked the metal effect on alkaline phosphatase enzyme in pasteurized milk for 24 hours in a water bath (D.K scientific technologies) at $36^{\circ} \mathrm{c}$. In this we have checked it by using five different metals one of that is copper (Samir tech chem. Industry, 30310). Here at $0.1 \%, 0.2 \%, 0.4 \%, 0.6 \%, 0.8 \%$, $1.0 \%$ concentration the alkaline phosphatase enzyme does not reactivate in the pasteurized milk for 24 hour.

Table 2.Readings of Copper test samples

\begin{tabular}{|c|c|c|c|c|c|c|}
\hline & \multicolumn{6}{|c|}{ Copper solution concentration effect on ALP test } \\
\hline Time (Hrs) & $0.10 \%$ & $0.20 \%$ & $0.40 \%$ & $0.60 \%$ & $0.80 \%$ & $1.00 \%$ \\
\hline 0 & Negative & Negative & Negative & Negative & Negative & Negative \\
\hline 1 & Negative & Negative & Negative & Negative & Negative & Negative \\
\hline 2 & Negative & Negative & Negative & Negative & Negative & Negative \\
\hline 3 & Negative & Negative & Negative & Negative & Negative & Negative \\
\hline 4 & Negative & Negative & Negative & Negative & Negative & Negative \\
\hline 5 & Negative & Negative & Negative & Negative & Negative & Negative \\
\hline 6 & Negative & Negative & Negative & Negative & Negative & Negative \\
\hline 7 & Negative & Negative & Negative & Negative & Negative & Negative \\
\hline 8 & Negative & Negative & Negative & Negative & Negative & Negative \\
\hline 9 & Negative & Negative & Negative & Negative & Negative & Negative \\
\hline 10 & Negative & Negative & Negative & Negative & Negative & Negative \\
\hline 11 & Negative & Negative & Negative & Negative & Negative & Negative \\
\hline 12 & Negative & Negative & Negative & Negative & Negative & Negative \\
\hline 13 & Negative & Negative & Negative & Negative & Negative & Negative \\
\hline 14 & Negative & Negative & Negative & Negative & Negative & Negative \\
\hline 15 & Negative & Negative & Negative & Negative & Negative & Negative \\
\hline 16 & Negative & Negative & Negative & Negative & Negative & Negative \\
\hline 17 & Negative & Negative & Negative & Negative & Negative & Negative \\
\hline 18 & Negative & Negative & Negative & Negative & Negative & Negative \\
\hline 19 & Negative & Negative & Negative & Negative & Negative & Negative \\
\hline 20 & Negative & Negative & Negative & Negative & Negative & Negative \\
\hline 21 & Negative & Negative & Negative & Negative & Negative & Negative \\
\hline 22 & Negative & Negative & Negative & Negative & Negative & Negative \\
\hline 23 & Negative & Negative & Negative & Negative & Negative & Negative \\
\hline 24 & Negative & Negative & Negative & Negative & Negative & Negative \\
\hline
\end{tabular}




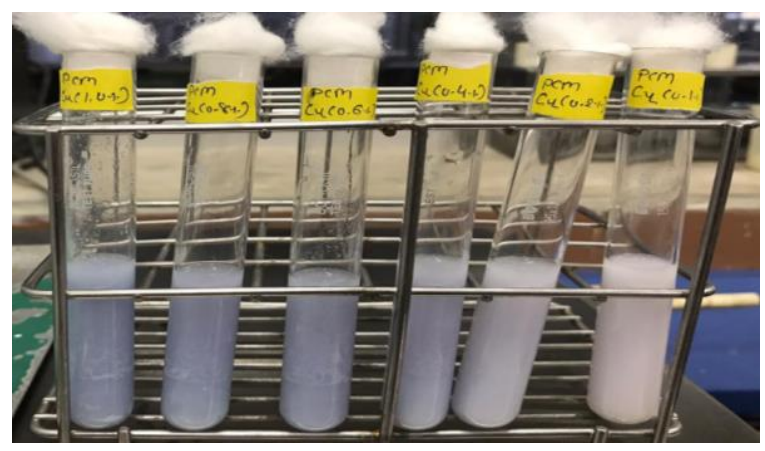

Figure 5. Reading of copper test samples at 0 hour
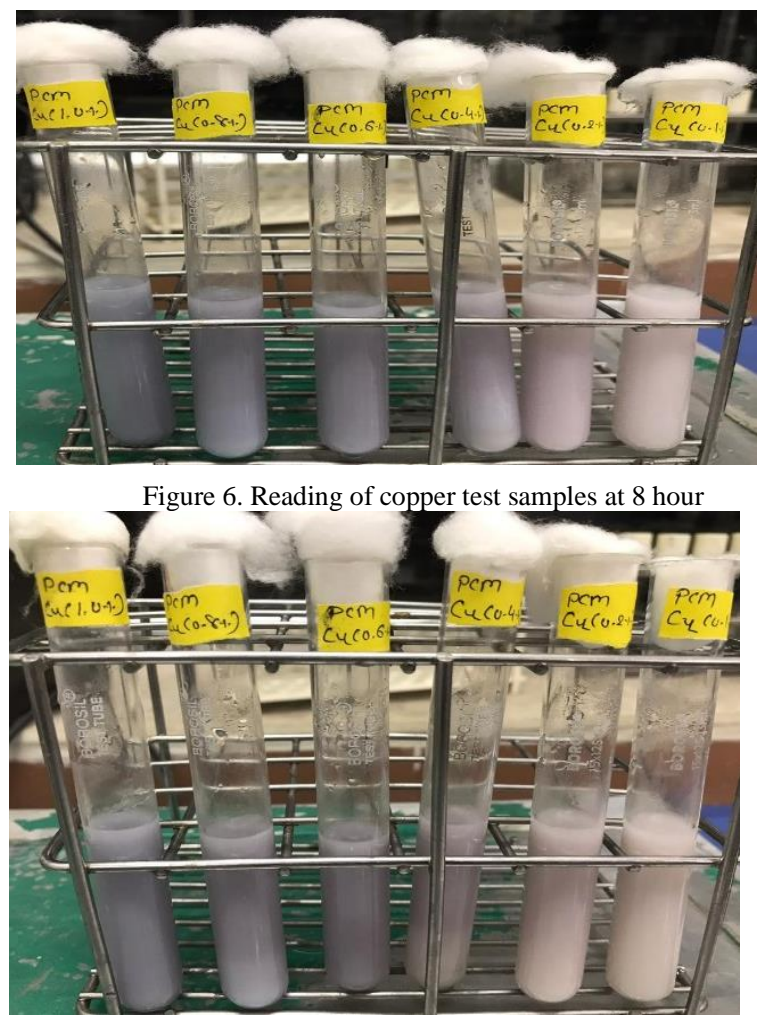

Figure 7. Reading of copper test samples at 16 hour

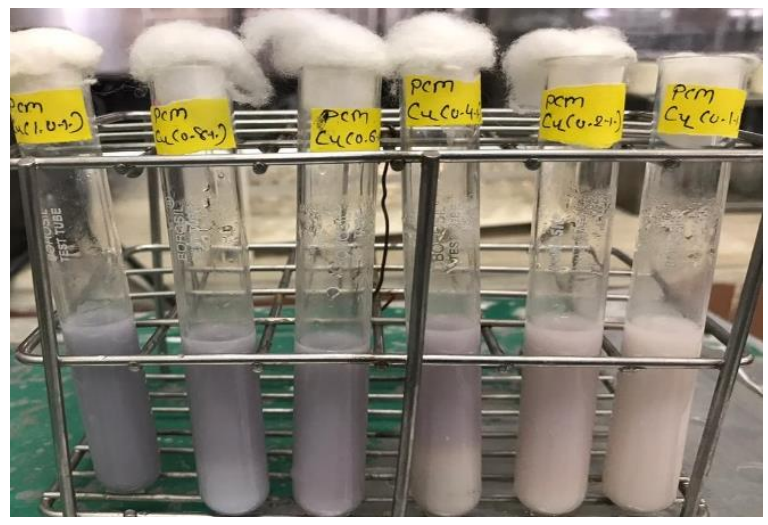

Figure 8. Reading of copper test samples at 24 hour 
Zinc (S D fine chem. Limited, $20297 \mathrm{k05}$ )

We have checked the activity of metals on alkaline phosphatase enzyme reactivation. In this we have made different concentration of metal solution of $0.1 \%, 0.2 \%, 0.4 \%, 0.6 \%, 0.8 \%$ and $1.0 \%$ by this different concentration we can check the time required for the reactivation of the alkaline phosphatase enzyme in the pasteurized, milk. We have checked the metal effect on alkaline phosphatase enzyme in pasteurized milk for 24 hours in a water bath (D.K scientific technologies) at $36^{\circ} \mathrm{c}$. In this we have checked it by using five different metals one of that is zinc(S D fine chem. Limited, $20297 \mathrm{k} 05)$. Here at different time the alkaline phosphatase enzyme gets activate in the pasteurized milk which is shown in the below table,

Table 3.Readings of zinc test samples

\begin{tabular}{|c|c|c|c|c|c|c|}
\hline \multirow[b]{2}{*}{ Time (Hrs) } & \multicolumn{6}{|c|}{ Zinc solution concentration effect on ALP test } \\
\hline & $0.10 \%$ & $0.20 \%$ & $0.40 \%$ & $0.60 \%$ & $0.80 \%$ & $1.00 \%$ \\
\hline 0 & Negative & Negative & Negative & Negative & Negative & Negative \\
\hline 1 & Negative & Negative & Negative & Negative & Negative & Negative \\
\hline 2 & Negative & Negative & Negative & Negative & Negative & Negative \\
\hline 3 & Negative & Negative & Negative & Negative & Negative & Negative \\
\hline 4 & Negative & Negative & Negative & Negative & Negative & Negative \\
\hline 5 & Negative & Negative & Negative & Negative & Negative & Negative \\
\hline 6 & Negative & Negative & Negative & Negative & Negative & Negative \\
\hline 7 & Positive & Negative & Negative & Negative & Negative & Negative \\
\hline 8 & Positive & Positive & Negative & Negative & Negative & Negative \\
\hline 9 & Positive & Positive & Positive & Negative & Negative & Negative \\
\hline 10 & Positive & Positive & Positive & Negative & Negative & Negative \\
\hline 11 & Positive & Positive & Positive & Positive & Negative & Negative \\
\hline 12 & Positive & Positive & Positive & Positive & Positive & Negative \\
\hline 13 & Positive & Positive & Positive & Positive & Positive & Negative \\
\hline 14 & Positive & Positive & Positive & Positive & Positive & Positive \\
\hline 15 & Positive & Positive & Positive & Positive & Positive & Positive \\
\hline 16 & Positive & Positive & Positive & Positive & Positive & Positive \\
\hline 17 & Positive & Positive & Positive & Positive & Positive & Positive \\
\hline 18 & Positive & Positive & Positive & Positive & Positive & Positive \\
\hline 19 & Positive & Positive & Positive & Positive & Positive & Positive \\
\hline 20 & Positive & Positive & Positive & Positive & Positive & Positive \\
\hline 21 & Positive & Positive & Positive & Positive & Positive & Positive \\
\hline 22 & Positive & Positive & Positive & Positive & Positive & Positive \\
\hline 23 & Positive & Positive & Positive & Positive & Positive & Positive \\
\hline 24 & Positive & Positive & Positive & Positive & Positive & Positive \\
\hline
\end{tabular}

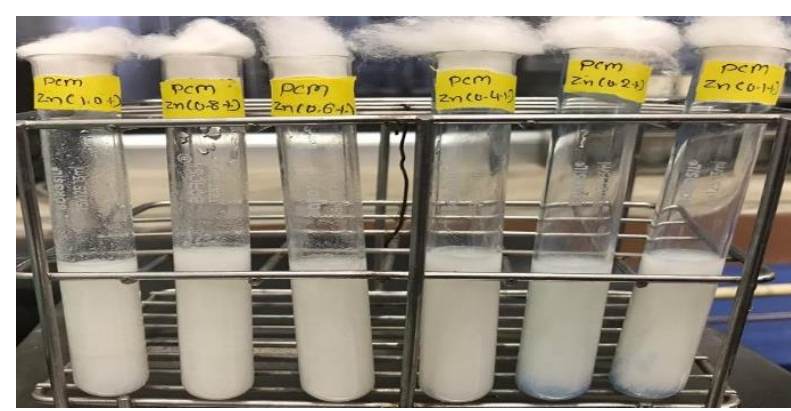

Figure 9. Reading of zinc test samples at 0 hour

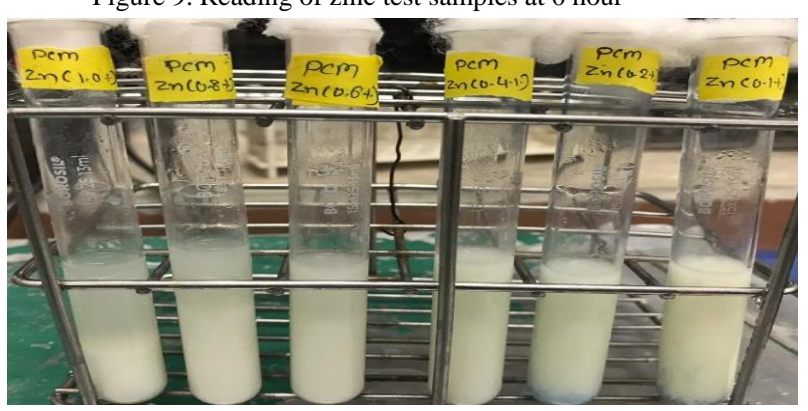

Figure 10. Reading of zinc test samples at 7 hour 


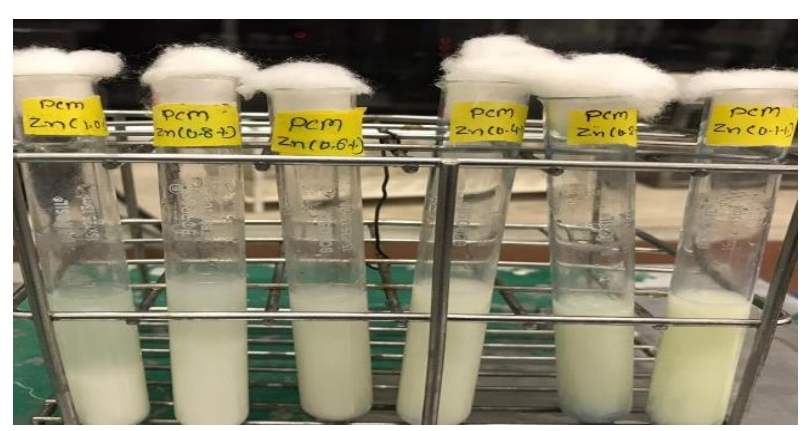

Figure 11. Reading of zinc test samples at 8 hour

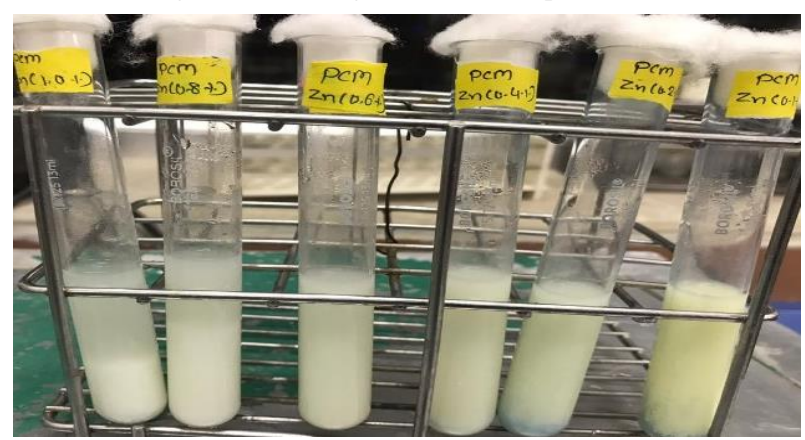

Figure 12. Reading of zinc test samples at 9 hour
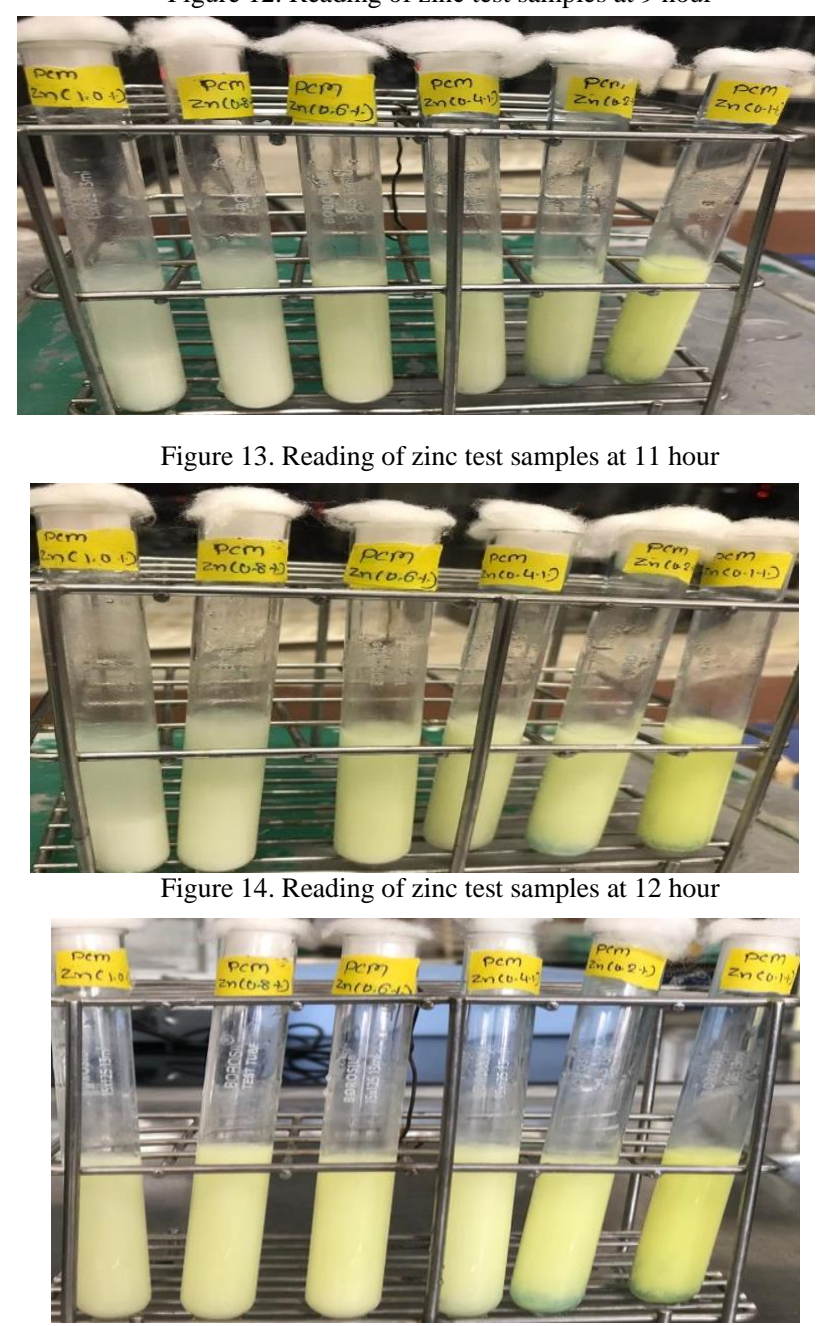

Figure 15. Reading of zinc test samples at 14 hour 
Manganese

We have checked the activity of metals on alkaline phosphatase enzyme reactivation. In this we have made different concentration of metal solution of $0.1 \%, 0.2 \%, 0.4 \%, 0.6 \%, 0.8 \%$ and $1.0 \%$ by this different concentration we can check the time required for the reactivation of the alkaline phosphatase enzyme in the pasteurized, milk. We have checked the metal effect on alkaline phosphatase enzyme in pasteurized milk for 24 hours in a water bath (D.K scientific technologies) at $36^{\circ} \mathrm{c}$. In this we have checked it by using five different metals one of that is manganese. Here at different time the alkaline phosphatase enzyme gets activate in the pasteurized milk which is shown in the below table,

Table 4.Readings of manganese test samples

\begin{tabular}{|c|c|c|c|c|c|c|}
\hline \multirow[b]{2}{*}{ Time (Hrs) } & \multicolumn{6}{|c|}{ Manganese solution concentration effect on ALP test } \\
\hline & $0.10 \%$ & $0.20 \%$ & $0.40 \%$ & $0.60 \%$ & $0.80 \%$ & $1.00 \%$ \\
\hline 0 & Negative & Negative & Negative & Negative & Negative & Negative \\
\hline 1 & Negative & Negative & Negative & Negative & Negative & Negative \\
\hline 2 & Negative & Negative & Negative & Negative & Negative & Negative \\
\hline 3 & Negative & Negative & Negative & Negative & Negative & Negative \\
\hline 4 & Negative & Negative & Negative & Negative & Negative & Negative \\
\hline 5 & Negative & Negative & Negative & Negative & Negative & Negative \\
\hline 6 & Negative & Negative & Negative & Negative & Negative & Negative \\
\hline 7 & Negative & Negative & Negative & Negative & Negative & Negative \\
\hline 8 & Negative & Negative & Negative & Negative & Negative & Negative \\
\hline 9 & Positive & Positive & Negative & Negative & Negative & Negative \\
\hline 10 & Positive & Positive & Negative & Negative & Negative & Negative \\
\hline 11 & Positive & Positive & Positive & Negative & Negative & Negative \\
\hline 12 & Positive & Positive & Positive & Positive & Positive & Negative \\
\hline 13 & Positive & Positive & Positive & Positive & Positive & Negative \\
\hline 14 & Positive & Positive & Positive & Positive & Positive & Positive \\
\hline 15 & Positive & Positive & Positive & Positive & Positive & Positive \\
\hline 16 & Positive & Positive & Positive & Positive & Positive & Positive \\
\hline 17 & Positive & Positive & Positive & Positive & Positive & Positive \\
\hline 18 & Positive & Positive & Positive & Positive & Positive & Positive \\
\hline 19 & Positive & Positive & Positive & Positive & Positive & Positive \\
\hline 20 & Positive & Positive & Positive & Positive & Positive & Positive \\
\hline 21 & Positive & Positive & Positive & Positive & Positive & Positive \\
\hline 22 & Positive & Positive & Positive & Positive & Positive & Positive \\
\hline 23 & Positive & Positive & Positive & Positive & Positive & Positive \\
\hline 24 & Positive & Positive & Positive & Positive & Positive & Positive \\
\hline
\end{tabular}

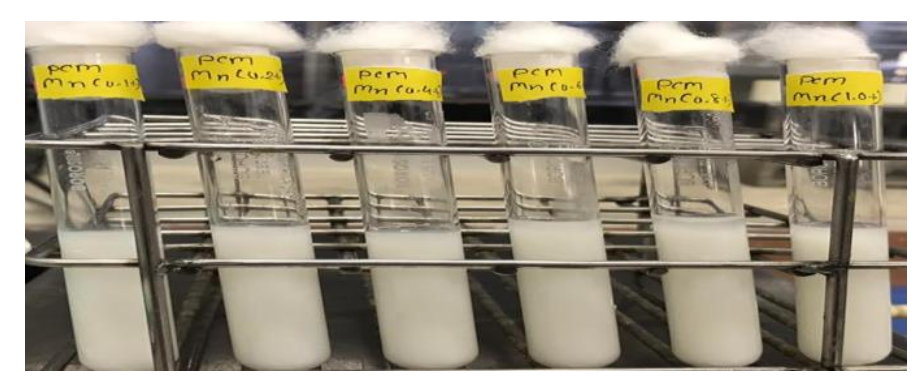

Figure 16.Readings of manganese test samples at 0 hour

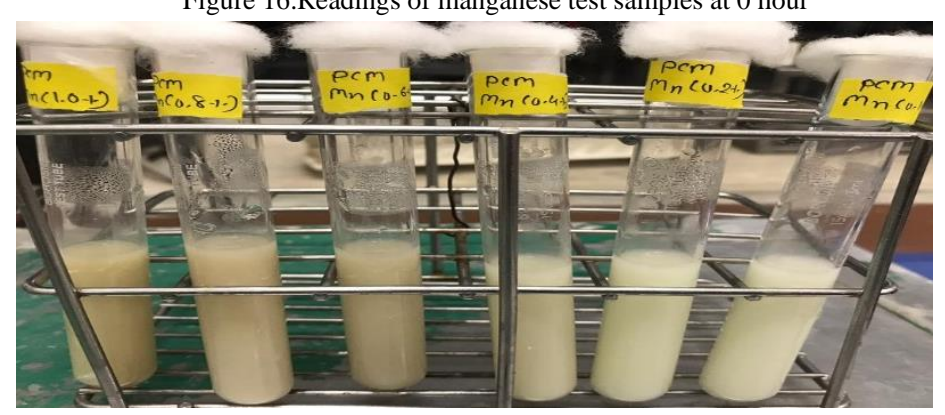

Figure 17.Readings of manganese test samples at 9 hour 


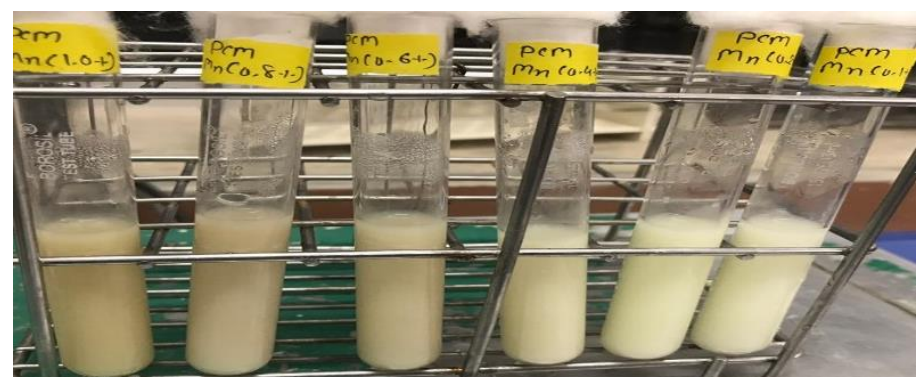

Figure 18.Readings of manganese test samples at 11 hour

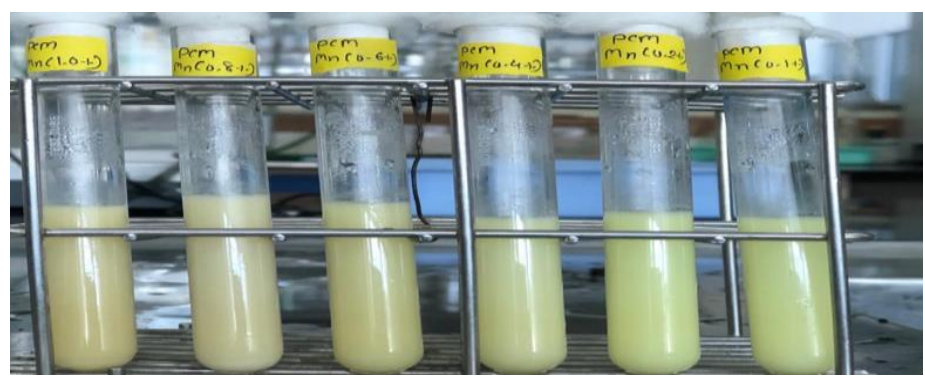

Figure 19.Readings of manganese test samples at 12 hour

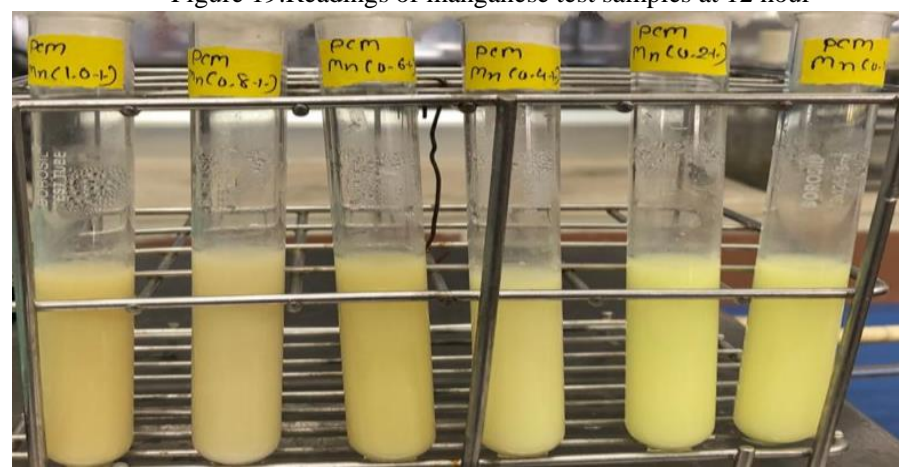

Figure 19.Readings of manganese test samples at 14 hour

Cobalt (Glaxo smithkline pharmaceuticals, 59876209)

We have checked the activity of metals on alkaline phosphatase enzyme reactivation. In this we have made different concentration of metal solution of $0.1 \%, 0.2 \%, 0.4 \%, 0.6 \%, 0.8 \%$ and $1.0 \%$ by this different concentration we can check the time required for the reactivation of the alkaline phosphatase enzyme in the pasteurized, milk.

We have checked the metal effect on alkaline phosphatase enzyme in pasteurized milk for 24 hours in a water bath (D.K scientific technologies) at $36^{\circ} \mathrm{c}$. In this we have checked it by using five different metals one of that is cobalt (Glaxo smithkline pharmaceuticals, 59876209). Here at different time the alkaline phosphatase enzyme gets activate in the pasteurized milk which is shown in the below table,

Table 5.Readings of cobalt test samples

\begin{tabular}{|l|l|l|l|l|l|l|}
\hline \multicolumn{7}{|c|}{ Cobalt solution concentration effect on ALP test } \\
\hline Time (Hrs) & $0.10 \%$ & $0.20 \%$ & $0.40 \%$ & $0.60 \%$ & $0.80 \%$ & $1.00 \%$ \\
\hline 0 & Negative & Negative & Negative & Negative & Negative & Negative \\
\hline 1 & Negative & Negative & Negative & Negative & Negative & Negative \\
\hline 2 & Negative & Negative & Negative & Negative & Negative & Negative \\
\hline 3 & Negative & Negative & Negative & Negative & Negative & Negative \\
\hline 4 & Negative & Negative & Negative & Negative & Negative & Negative \\
\hline 5 & Negative & Negative & Negative & Negative & Negative & Negative \\
\hline 6 & Negative & Negative & Negative & Negative & Negative & Negative \\
\hline 7 & Negative & Negative & Negative & Negative & Negative & Negative \\
\hline 8 & Negative & Negative & Negative & Negative & Negative & Negative \\
\hline 9 & Negative & Negative & Negative & Negative & Negative & Negative \\
\hline 10 & Negative & Negative & Negative & Negative & Negative & Negative \\
\hline 11 & Negative & Negative & Negative & Negative & Negative & Negative \\
\hline 12 & Negative & Negative & Negative & Negative & Negative & Negative \\
\hline 13 & Negative & Negative & Negative & Negative & Negative & Negative \\
\hline 14 & Negative & Negative & Negative & Negative & Negative & Negative \\
\hline 15 & Positive & Positive & Negative & Negative & Negative & Negative \\
\hline 16 & Positive & Positive & Positive & Negative & Negative & Negative \\
\hline
\end{tabular}




\begin{tabular}{|l|l|l|l|l|l|l|}
17 & Positive & Positive & Positive & Negative & Negative & Negative \\
\hline 18 & Positive & Positive & Positive & Negative & Negative & Negative \\
\hline 19 & Positive & Positive & Positive & Negative & Negative & Negative \\
\hline 20 & Positive & Positive & Positive & Negative & Negative & Negative \\
\hline 21 & Positive & Positive & Positive & Negative & Negative & Negative \\
\hline 22 & Positive & Positive & Positive & Negative & Negative & Negative \\
\hline 23 & Positive & Positive & Positive & Negative & Negative & Negative \\
\hline 24 & Positive & Positive & Positive & Negative & Negative & Negative \\
\hline
\end{tabular}
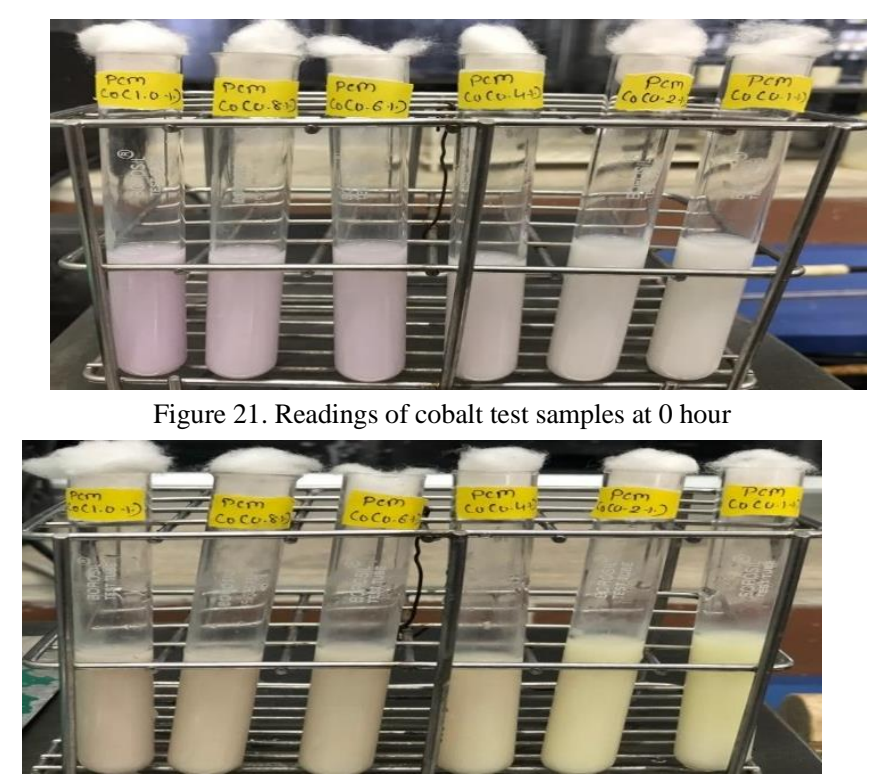

Figure 22. Readings of cobalt test samples at 15 hour

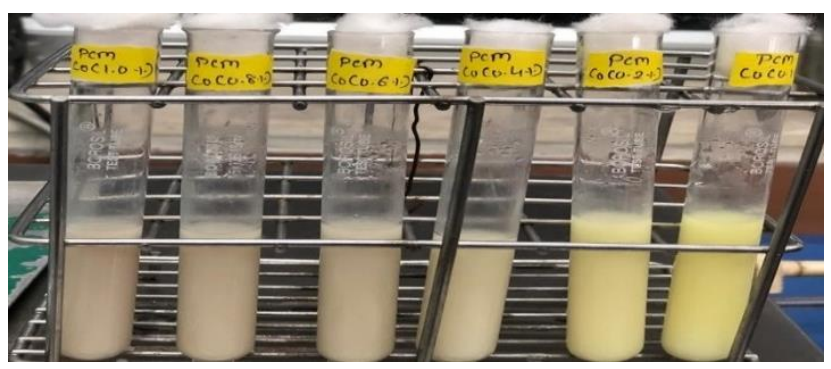

Figure 23. Readings of cobalt test samples at 16 hour

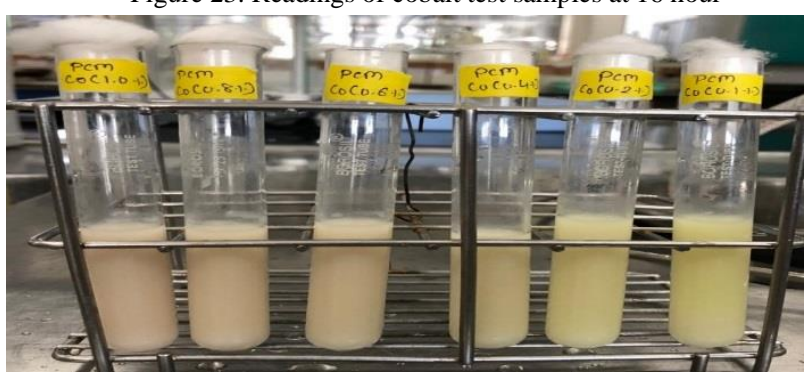

Figure 24. Readings of cobalt test samples at 17 hour

Calcium (Samir tech chem. Private limited, 910443)

We have checked the activity of metals on alkaline phosphatase enzyme reactivation. In this we have made different concentration of metal solution of $0.1 \%, 0.2 \%, 0.4 \%, 0.6 \%, 0.8 \%$ and $1.0 \%$ by this different concentration we can check the time required for the reactivation of the alkaline phosphatase enzyme in the pasteurized, milk. We have checked the metal effect on alkaline phosphatase enzyme in pasteurized milk for 24 hours in a water bath (D.K scientific technologies) at $36^{\circ} \mathrm{c}$. In this we have checked it by using five different metals one of that is calcium (Samir tech chem. Private limited, 910443). Here at different time the alkaline phosphatase enzyme gets activate in the pasteurized milk which is shown in the below table, 
Table 6.Readings of calcium test samples

\begin{tabular}{|c|c|c|c|c|c|c|}
\hline \multirow[b]{2}{*}{ Time (Hrs) } & \multicolumn{6}{|c|}{ Calcium solution concentration effect on ALP test } \\
\hline & $0.10 \%$ & $0.20 \%$ & $0.40 \%$ & $0.60 \%$ & $0.80 \%$ & $1.00 \%$ \\
\hline 0 & Negative & Negative & Negative & Negative & Negative & Negative \\
\hline 1 & Negative & Negative & Negative & Negative & Negative & Negative \\
\hline 2 & Negative & Negative & Negative & Negative & Negative & Negative \\
\hline 3 & Positive & Negative & Positive & Negative & Negative & Negative \\
\hline 4 & Positive & Negative & Positive & Negative & Negative & Negative \\
\hline 5 & Positive & Negative & Positive & Negative & Negative & Negative \\
\hline 6 & Positive & Negative & Positive & Negative & Negative & Negative \\
\hline 7 & Positive & Negative & Positive & Positive & Negative & Positive \\
\hline 8 & Positive & Positive & Positive & Positive & Positive & Positive \\
\hline 9 & Positive & Positive & Positive & Positive & Positive & Positive \\
\hline 10 & Positive & Positive & Positive & Positive & Positive & Positive \\
\hline 11 & Positive & Positive & Positive & Positive & Positive & Positive \\
\hline 12 & Positive & Positive & Positive & Positive & Positive & Positive \\
\hline 13 & Positive & Positive & Positive & Positive & Positive & Positive \\
\hline 14 & Positive & Positive & Positive & Positive & Positive & Positive \\
\hline 15 & Positive & Positive & Positive & Positive & Positive & Positive \\
\hline 16 & Positive & Positive & Positive & Positive & Positive & Positive \\
\hline 17 & Positive & Positive & Positive & Positive & Positive & Positive \\
\hline 18 & Positive & Positive & Positive & Positive & Positive & Positive \\
\hline 19 & Positive & Positive & Positive & Positive & Positive & Positive \\
\hline 20 & Positive & Positive & Positive & Positive & Positive & Positive \\
\hline 21 & Positive & Positive & Positive & Positive & Positive & Positive \\
\hline 22 & Positive & Positive & Positive & Positive & Positive & Positive \\
\hline 23 & Positive & Positive & Positive & Positive & Positive & Positive \\
\hline 24 & Positive & Positive & Positive & Positive & Positive & Positive \\
\hline
\end{tabular}

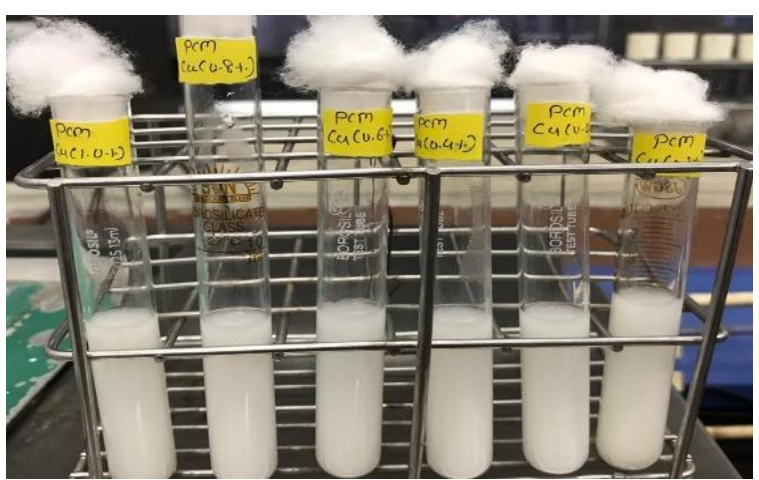

Figure 25. Readings of calcium test samples at 0 hour

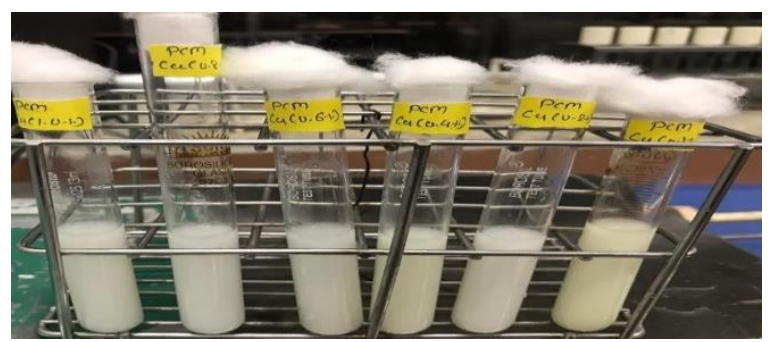

Figure 26. Readings of calcium test samples at 3 hour

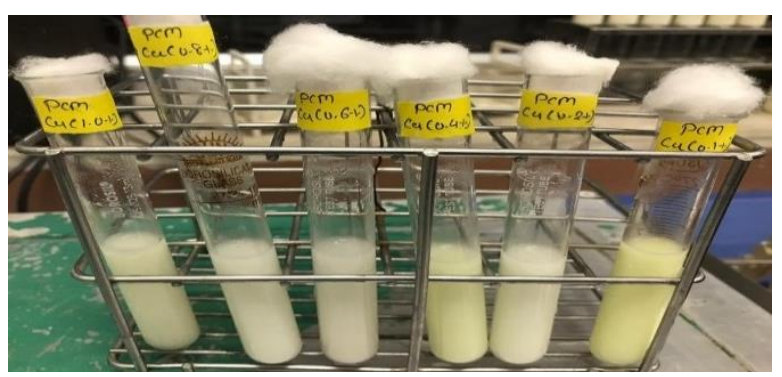

Figure 27. Readings of calcium test samples at 7 hour 


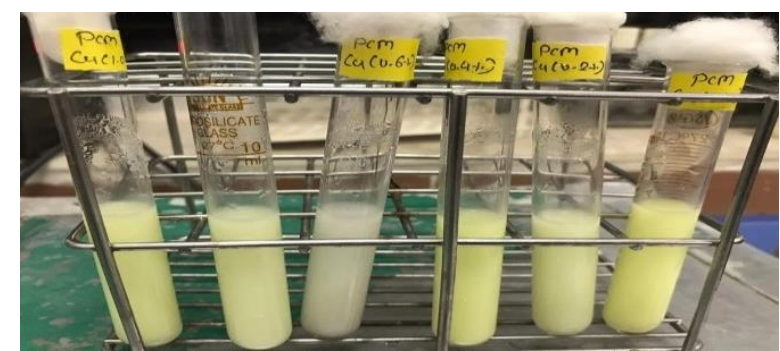

Figure 28. Readings of calcium test samples at 8 hour

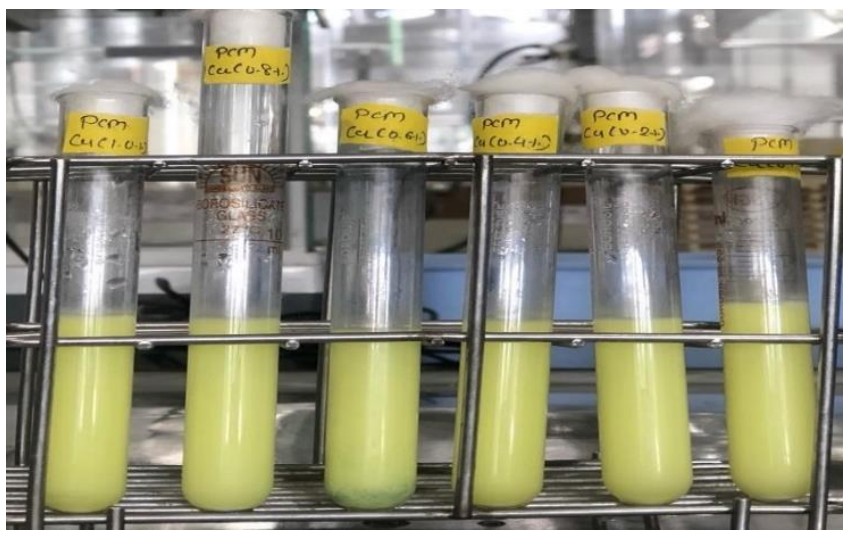

Figure 29. Readings of calcium test samples at 9 hour

\section{DISCUSSION}

Alkaline phosphatase which is the enzyme present in the milk gets inactivated by undergoing heat treatment at around $72{ }^{\circ} \mathrm{c}$ for few seconds which coincides with the heat treatment given to the raw milk which is known as pasteurization. Here in raw milk the alkaline phosphatase enzyme is present which can be identify by using the above procedure and as a result it shows yellow colour precipitates because in raw milk Alkaline phosphatase enzyme acts on phosphoester bond of pera nitro phenyl phosphate and upon enzymatic hydrolysis of this pera nitro phenyl phosphate the pera nitro phenol forms as a product and due to this reaction it gives yellow colour. Raw milk will give yellow colour precipitates when we add buffer solution.

While in pasteurized milk it takes time to get reactive again. As shown in result the pasteurized milk will take approximately 6 hour for the reactivation of the alkaline phosphatase enzyme. Here along we have taken the pasteurized milk sample as the Reference sample. As for the five metal samples that are Zinc (S D fine chem. Limited, $20297 \mathrm{k05}$ ), Copper (Samir tech chem. Industry, 30310), Cobalt (Glaxo smith Kline pharmaceuticals, 59876209), Calcium (Samir tech chem. Private limited, 910443) and Manganese except for the copper other than that other 4 metal samples of different concentration are showing the reactivation of the alkaline phosphatase enzyme into the pasteurized milk. As shown above in the results the calcium is the first one in which the alkaline phosphatase enzyme gets active and after this in zinc, manganese and cobalt the alkaline phosphatase enzyme gets activated in $0.1 \%$ calcium concentration sample. While in copper sample it does not show any activity for 24 hours.

\section{CONCLUSION}

Milk is considered as the whole food because it contains all the essential nutrients and due to this the consumption of milk is higher. To identify the quality of pasteurized milk all dairy industry takes tests in which APL activity test is important to know the inactivation of index microorganism but along with that if we also get to know the presence of metal ions so it will be more helpful to the industry so that instead of two or more test we can identify the presence of ions by APL activity test only.

From above study we can say that the copper metal ion is the highly inhibited one in pasteurized milk while the cobalt is semi inhibiting the reactivation of alkaline phosphatase enzyme. While the calcium is highly exhibiting the reactivation of alkaline phosphatase enzyme along with calcium the cobalt and manganese also exhibits the reactivation of the alkaline phosphatase enzyme.

\section{FUTURE SCOPE}

India is the world's largest milk producer which contributes 22 percent to the global production of milk. So with the highest production it also requires to maintain quality of the milk. This study was aimed to examine the reactivation of alkaline phosphatase enzyme into the pasteurized milk. It is a qualitative test which only shows that the test is negative or positive but further more can be done. In this study we can further go and find the quantity of metal ions present into the milk. Along with this we can also find the individual metal ion effect into the body. We can also further study the influence of different metal ions on the physical properties of pasteurized milk. 
[1] L.A.Richardson, E.F.McFarren and J.E.Campbell, Phosphatase reactivation, Mlik and food research, Robert A. taft sanitary engineering canter, U.S Development of health, education and welfare, public health service Cincinnati, Ohio, page no.206.

[2] G.K.Murthy, s.Cox, and L.kaylor, Reactivation of alkaline Phosphatase in ultra high temperature, short time processed liquid milk producrs, Journalof dairy science vol.59, no.10, page no.1699

[3] Sandhya M. Sonawane, ISOR Jornal of pharmacywww.isophr.org, volume 7, issue 1 (July 2017), page no.53 \&54

[4] Maitha M. Alnuaimi, Ibtesam A. Saeed, and S.salman Ashraf, Effect of various heavy metals on the enzymatic activity of E.coli Alkaline Phosphatase, International Journal of Biotechnology and Biochemistry, volume 8, number 1(2012), page no.47\&50

[5] Harding F (1991) Alkaline phosphatase test as a measure of correct pasteurization. Bullet in 262 Int Dairy Fed, Brussels, Belgium.

[6] Suzuki U, Yoshimura K, Takaishi M (1907) Ubereinenzym "phytase"dasanhydro-oxy-methylen-diphosphorsaurespaltet. Bull CollAgric Tokyo Imp Univ 7: $503-512$

[7] Shakeel Ur Rehman, Fleming CM ,Farkye NY, Fox PF (2003) Indigenous phosphatases in milk. In. Advanced Dairy Chemistry, pp. 523-544.

[8] Miggiano GA, A Mordente, GE Martorana, E Meucci and A Castelli (1983) In-vitro effect of ascorbicacid on bovine kidney alkaline phosphatase activity ActaVitaminolEnzymol 5(3): 153-158.

[9] Schlimme E, Kiesner C, Lorenzen PC, Martin D (1997) Chemical process parameters for thermal inactivation of alkaline phosphatase in milk KielerMilchwForsch 49(3): 207-219.

[10] Bortolato MF, Besson, M Roux (2002) An infrared study of the thermal and pH stabilities of the GPI-alkaline phosphatase from bovine intestine. BiochemBiophys Res Commun 292(4): 874-879.

[11] Vega-Warner AV, Wang CH, Smith DM, Ustunol Z (1999) Milk alkaline phosphatase purification and production of poly-clonal antibodies. J FoodSci 64(4): 601-605.

[12] Wright RC, Tramer J (1956) Reactivation of milk phosphatase following heat treatment IV. The influence of certain metallic ions. J Dairy Res 23(2): 248-

[13] Kosikowski FV (1988) Enzyme behavior and utilization in dairy technology. J Dairy Sci 71(3): 557-573.

[14] Haab W, LM Smith (1956) Variations in alkaline phosphatase activity of milk. J Dairy Sci 39(12): 1644-1650.

[15] Murthy GK, Kleyn DH, Ichardson TR, Rocco RM (1992) Alkaline phosphatase methods. Standard Methods for the Examination of Dairy Products. Am Publ Health Assoc Washington, USA

[16] Burgwald LH (1939) The phosphatase test. A review of the literature on its application for detecting irregularities in the pasteurization of milk and dairy products. J Dairy Sci 22(10): 853-872.

[17] Murthy GK, Martin R, Rhea US, Peeler JT (1979) Rapid colorimetric test for alkaline phosphatase in dairy food products. J Food Prot 42(10): $794-799$

[18] Sanders GP, Sager OS (1948) Heat inactivation milk phosphatase in dairy products. J Dairy Sci 31(10): 845-857

[19] Eckner KF (1992) Fluoro metric analysis of alkaline phosphatase in activation correlated to Salmonella and Listeria in activation. J Food Prot 55: 960-963.

[20] Picart LM, Thiebaud, Rene M, Guiraud JP, Cheftel JC, et al. (2006) Effects of high pressure homogenization of raw bovine milk on alkaline phosphatase and microbial inactivation. A comparison with continuous short-time thermal treatments. J Dairy Res 73(4): 454-463.

[21] Shamsi K, Versteeg C, Sherkat F, Wan J (2008) Alkaline phosphatase and microbial inactivation by pulsed electric field in bovine milk. Innov Food SciEmergTechnol 9(2): 217-223

[22] McKellar RC, HW Modler, H Couture, A Hughes, P Mayers, et al. (1994) Predictive modeling of alkaline-phosphatase in activation in a high- temperature short-time pasteurizer. J Food Prot 57: 424-430.

[23] Rocco RM (2004) Standard Methods for the Examination of Dairy Products. In. Alkaline phosphatase methods. Wehrand HM, Frank JF American Public Health Association, Washington, USA

[24] Kay HD, WR Graham (1935) The phosphatase test for pasteurized milk. J Dairy Res 6: 191-203

[25] Scharer H (1938) A rapid phosphor monoesterase test for control of dairy pasteurization. J Dairy Sci 21: 21-34

[26] Scharer H (1943) Laboratory control of milk under war conditions. The rapid phosphatase test. Am J Public Health Nations Health 33(4): $396-398$.

[27] Angelino PD, GL Christen, MP Penfield, S Beattie (1999) Residual alkaline phosphatase activity in pasteurized milk heated to various temperatures measurement with the Fluorophos and Scharer rapid phosphatase tests. J Food Prot 62(1): 81-85.

[28] Babson AL, SJ Greeley (1967) New substrate for alkaline phosphatase in milk. J AssocOff Anal Chem 50: 555-557.

[29] A schaffen burg R, JEC Mullen (1949) A rapid and simple phosphatase test for milk J DairyRes16(1): 58-67.

[30] Fernley HN, PG Walker (1965) Kinetic behavior of calf -intestinal alkaline phosphatase with 4-methyl umbelliferyl phosphate. Bio chem J 97(1): 95-103.

[31] Yoshitomi K (2004) Alkaline phosphatase activity in cheeses measured by fluorometry. Int J Food SciTechnol 39(3): 349-353.

[32] Fox PF, AL Kelly (2006) Indigenous enzymes in milk:Over-view and historical aspects Part2. Int Dairy J 16(6): 517-532.

[33] Fenoll J, G Jourquin, JM Kauffmann (2002) Fluorimetric de-termination of alkaline phosphatase in solid and fluid dairy products. Talanta 56(6): 1021-1026

[34] Payne C, Wilbey RA (2009) Alkaline phosphatase activity in pasteurized milk: A quantitative comparison of Fluorophos and colourimetric procedures. Int J Dairy Technol 62(3): 308-314.

[35] Black RG, M Kuzyk, J Duggan (1993) Evaluation of afluorometric assay for alkaline phosphatase in fluid dairy products. Aust J Dairy Technol 47: 164167.

[36] Claeys WL, AM vanLoey, ME Hendrickz (2002) Kinetics of alkaline phosphatase and lacto peroxidase inactivation, and of $\beta$-lacto globulin denaturation in milk with different fat content. J Dairy Res 69(4): 541- 553.

[37] Girotti S, E Ferri, S Ghini, R Budini, A Roda (1994) Chemiluminescent assay of alkaline phosphatase in milk. Neth Milk Dairy J 48(4): 213-224.

[38] Painter CJ, Bradley RL (1997) Residual alkaline phosphatase activity in milks subjected to various time temperature treatments. J Food Prot 60: 525-530.

[39] Kuzuya Y, Y Kanamaru, TT anahashi (1982) Purification of bovine milk alkaline phosphatase with affinity chromatography and effect of flavonoids and saccharides on the enzyme activities. Nippon ChikusanGakkaiho 53(1): 45-49.

[40] Linden G (1979) Biochemical study of some aspects of milk alkaline phosphatase reactivation. Milchwissenschaft 34: 329-332.

[41] Sanders GP, Sager OS, Hupfer JA (1954) Factors affecting the sensitivity and accuracy of the phosphatase test. J Dairy Sci 37(6): 698-710.

[42] Ma Y, DM Barbano, JH Hotch kiss, S Murphy, JM Lynch (2001) Impact of CO2 addition to milk on selected analytical testing methods. J Dairy Sci 84(9): 1959-1968.

[43] Murthy GK, Cox S, Kalyor L (1976) Reactivation of alkaline phosphatase in ultra high temperature, short-time processed liquid milk products. J Dairy Sci 59(10): 1699-1710.

[44] Murthy GK, Cox S (1988) Evaluation of APHA and AOAC methods for phosphatase in cheese. J AssocOff Anal Chem 71(6): 1195-1199.

[45] Knight AH, SM Fryer (1989) The development of heat resistant phosphatase activity in raw milk. J Soc Dairy Technol 42: 81-86.

[46] Murthy GK, Kaylor LO (1990) Evaluation of APHA and AOAC II methods for phosphatase in butter and differentiation of milk and microbial phosphatase by agarose-gel electrophoresis. J Assoc off Anal Chem 73: 681-687.

[47] Rosenthal I, Bernstein S, Rosen B (1996) Alkaline phosphatase activity in Penicilliumroqueforti and in blue-veined cheeses. J Dairy Sci 79(1): 16-19.

[48] Harding F, E Garry (2005) Collaborative evaluation of a fluorometric method for measuring alkaline phosphatase activity in cow's, sheep's, and goat's milk. J Food Prot 68(5): 1047-1053.

[49] Moatsou G (2010) Indigenous enzymatic activities in ovine and caprine milks. Int J Dairy Technol 63: 16-31

[50] Mathur MP (1974) Studies on alkaline phosphatase in goat milk. Indian J Dairy Sci 28: 145-147. 
[51] Williams DJ (1986) A modification to the Aschaffenburg and Mullen alkaline phosphatase test suitable for goat's milk. Aust J Dairy Technol 41: 28-30.

[52] Scintu MF, Daga E, Ledda A (2000) Evaluation of spectrophotometric and fluorometric methods for alkaline phosphatase activity determination in ewe's milk. J Food Prot 63(9): 1258-1261

[53] Klotz V, A Hill, K Warriner, M Griffiths, J Odumeru (2008) Assessment of the colorimetric and fluorometric assays for alkaline phosphatase activity in cow's, goat's, and sheep'smilk. J Food Prot 71: 1884-1888.

[54] RaynalLjutovaca K, Park YW, Gaucheron F, Bouhallab S (2007) Heat stability and enzymatic modifications of goat and sheep milk. Small Rumin Res 68(12): 207-220.

[55] Vamvakaki AN, Zoidou E, Moatsou G, Bokari M, Anifatakis E (2006) Residual alkaline phosphatase activity after heat treatment of ovine and caprine milk. Small Rumin Res 65(3): 237-241

[56] Anifantakis EM, PS Rosakis (1983) Alkaline phosphatase activity of sheep milk and some factors affecting it. Egyptian J Dairy Sci 11: $173-182$.

[57] Williams DJ, Nottingham SM (1990) Suitability of a modification to the Aschaffenburg and Mullen alkaline phosphatase test or goats'milk: Collaborative study. Aust J Dairy Technol 45(1): 21-23.

[58] Barbosa M (2005) Interest in controlling alkaline phosphatase activ-ity in sheep and goat milks. Pp. 117-127.

[59] Sharma RS, Ganguli N C (1974) Purification and properties of reactivated alkaline phosphatase from buffalo milk. Milchwissenschaft 29: 79-84.

[60] Lombardi P, L Avallone, AD Angelo, TM, E Bogin (2000) Buffalo-milk enzyme levels, their sensitivity to heat inactivation, and their possible use as markers for pasteurization. J Food Prot 63(7): 970-973.

[61] Sharma R, Kaur S, Rajput YS, Kumar R (2009) Activity and thermal stability of indigenous enzymes in cow, buffalo and goat milk. Milchwissenschaft 64(2): 173-175.

[62] Salter RS, Fitchen J (2006) Evaluation of a chemiluminescence method for measuring alkaline phosphatase activity in whole milk of multiple species and bovine dairy drinks: Inter laboratory study. J AOAC Int 89(4): 1061-1070.

[63] Wernery U, Fischbach S, Johnson B, Jose S (2008) Evaluation of Alkaline phosphatase(ALP), $\gamma$-Glutamyltransferase(GGT) and Lactoperoxidase(LPO) activities for their suitability as markers of camel milk heat inactivation. Milchwissenschaft 63(3): 265-267.

[64] Wernery U, Maier U, Johnson B, George RM, Braun F (2006) Comparative study on different enzymes evaluating heat treatment of dromedary milk Milchwissenschaft 61(1): 281-285.

[65] Kwee WS (1985) An improved Aschaffenburg and mullen alkaline phosphatase test for coloured milk products. Aust J Dairytechnol 40: 27-30.

[66] Shakeel Ur Rehman, Farkye NY, Yim B (2006) A preliminary study on the role of alkaline phosphatase in cheese ripening. Int Dairy J 16(6): 697-700.

[67] Battistotti BE, Brambilla F, Cappa, G Ferrandi (1997) Alkaline phosphatase in milk and ripened cheeses. SciTecnLattCas 48: 157-162.

[68] Pratt Lowe EL, Geiger RM, Richardson TRM (1988) Heat resistance of alkaline phosphatase produced by microorganisms isolated from California Mexican style cheeses. J Dairy Sci 71(1): 17-23.

[69] Karmas R, DH Kleyn (1990) Determination and interpretation of alkaline phosphatase activity in experimental and commercial butters. J Dairy Sci 73(3): 584-589.

[70] Peereboom CJW (1966) Studies on alkaline milk phosphatase I. Non- identity of rawand reactivated alkaline phosphatase from cream. Neth Milk Dairy J 20: $113-122$

[71] Peereboom CJW (1968) Studies on alkaline milk phosphatase II. Occurrence of various phosphatase isoenzymes in dairy products. Neth Milk Dairy J 22: $138-152$.

[72] Peereboom CJW (1969) Theory on therenaturation of alkaline milk phosphatase from pasteurized cream. Milchwissenschaft 24: 266-269.

[73] Wright RC, Tramer J (1953) Reactivation of milk phosphatase following heat treatment I. J Dairy Res 20(2): 177-188.

[74] Lyster RLJ, RA schaffen burg (1962) The reactivation of milk alkaline phosphatase after heat treatment. J Dairy Res 29(1): 21-35.

[75] Richardson LA, Mc Farren EF, Campbell JE (1964) Dynamic state of milk : Phosphatase reactivation. J Dairy Sci 47: 205-210.

[76] Linden G, DT Chappelet-Tordo, M Lazdunski (1977) Milk alkaline

[77] International Dairy Federation (1999) Milk and milk based drinks. Determination of alkaline phosphatase activity using a fluorimetric method. IDF-Standard 155A: 3 International Dairy Federation, Brussels, Belgium.

[78] Mc Kellar RC, H Cholette, DB Emmons (1988) Modification of the alkaline-phosphataseassay for butter Can. Inst Food SciTechnol J 21: 97-101.

[79] Schlimme E, Kiesner C, Lorenzen PC, Martin D (1998) Influence of heat treatment of milk on the activities of the indigenous milk enzymes alkaline phosphatase and adenosine deaminase. Bull Int Dairy Fed 332: 25-31.phosphatase simulation by Mg BiophysActa 483(1): 100-106.

[80] Serra B, Morales MD, Reviejo AJ, Hall EH, Pingarron JM (2005) Rapid and highly sensitive electrochemical determination of alkaline phosphatase using a composite tyrosinase biosensor. Anal Biochem 336(2): 289-294.

[81] Hassan SSM, HEM Sayour, AH Kamel (2009) A simple potentiometric method for determination of acid and alkaline phosphatase enzymes in biologica fluids and dairy products using a nitrophenyl phosphate plastic membrane sensor. Anal ChimActa 640(2): 75-81.

[82] Rocco RM (1990) Fluorometric determination of alkaline phosphatase in fluid dairy products: Collaborative study. J Assoc off Anal Chem 73(6):842-849.

\section{1.) Hetvi Pankajbhai Patel}

\section{AUTHOR'S INFORMATION}

She was doing her internship in Vidya dairy. She completed her Bachelor's Degree in Food Processing Technology from A.D.Patel Institute of Technology, Anand which is under Gujarat Technological University in 2020.

\section{2.) Abhay Ashvinbhai Koladiya}

He was doing his internship in Vidya dairy. He completed his Bachelor's Degree in Food Processing Technology from A.D.Patel Institute of Technology, Anand which is under Gujarat Technological University in 2020.

\section{3.) Divyesh Kanubhai Chauhan}

He is currently working in Vidya Dairy as an Executive since Oct-2006 to till date in QA Department, Anand, Gujarat, India. He also served for NDDB, Anand,Gujarat, India and SGS India Pvt. Ltd, Ahmedabad Gujarat,India as a Research Associate in between the year of 2003-2006. He did his Master's degree in Microbiology from Gujarat Vidyapeeth, Ahmedabad in 2003, graduated from Gujarat University, Ahmedabad in 2001. 